\title{
The Relationship between Capital and Bank Risk: Evidence from Tunisia
}

\author{
Mohamed Aymen Ben Moussa ${ }^{1}$ \\ ${ }^{1}$ Faculty of Economics and Management of Tunis, Tunis \\ Correspondence: Mohamed Aymen Ben Moussa, Faculty of Economics and Management of Tunis, Tunis. E-mail: \\ benmoussa.medaymen@planet.tn
}

Received: February 2, 2015

Accepted: February 9, 2015

Online Published: March 25, 2015

doi:10.5539/ijef.v7n4p223

URL: http://dx.doi.org/10.5539/ijef.v7n4p223

\begin{abstract}
The capital and risk are two important variables in banking. Indeed, capital can protect banks against shocks and excessive risks. But according to other researchers, there is a positive relationship between capital and risk.

In the context of this article, we looked at 18 banks in Tunisia over the period (2000-2010), we found that there is a negative relationship between the capital and bank risk by applying a static panel method.
\end{abstract}

Keywords: bank, capital, risk, panel

\section{Introduction}

The capital is important in banking. It can finance their investments and reduce the probability of bankruptcy. But the relationship between capital and bank risk is ambiguous. On the one hand, some researchers suggest that the capital increases the risk, others feel that capital reduces the risk.

Also this relationship depends on the regulations (capital requirement) and type of risk. The first studies that have examined the influence of capital requirements on bank solvency souch Kahane (1977), Kareben et Wallace (1978) Sharpe (1977) have shown that banks have incentives to increase risk taking.

Moreover, Kohen and Santomero (1980), Kim and Santomero (1988) showed that capital regulation may increase the risk taking of the bank.Indeed, Santos (1999) proved that an increase in capital requirement negatively encourages risk taking of the bank (reduced risk of bank insolvency). On the other hand, Kendall (1992) showed that higher capital requirement can cause a riskier behavior of the bank at times, but this does not imply a trends towards riskier banking system.

More recently, Abba et al. (2013), Fatnassi et al. (2014), Gosh (2014) found a significant relationship between capital and bank risk. As a result, the relationship between capital and bank risk is interesting to study. In the context of this article, we will discuss this relationship for 18 banks in Tunisia over the period (2000-2010), we will adopt a methodology composed of 3 sections. The first is devoted to the literature review, the second is related to the empirical study, finally, we will make a conclusion.

\section{Literature Review}

There are several studies that have explored the relationship between capital and bank risk. Aggrawal and Jacques (2001) found a positive and significant relationship between the change in level of capital and the risk of US banks respectively over the period of (1984-1987) and (1993-1997).

This relationship has been released by Rim (2001) in the case of swiss banks.

A positive relationship between the level of bank capital and risk assumes that banks have high levels of risk will try to increase their capital in order to avoid being penalized but also that banks with high capital level will engage in similar activities (Note 1).

But VANROY (2003), Godlewski (2004) found that changes in capital and risk are negatively related. Their results do not confirm those of Santomero (2003) according to which banks choose a riskier portfolio to offset the indirect loss by lower leverage.

In addition, Barth et al. (2004) showed that while more stringent capital requirements associated with some non performing loans, the relationship between regulatory capital and banking crises is not strong (this result is found 
after the control of other regulatory policies and supervisions) (Note 2).

Also Marshall and Prescott (2000) found that the need for capital reduces the probability of default and the risk of the portfolio. Roy (2003) has studied the impact of capital regulation on risk taking by commercial banks in 7 European countries, he found that the change in capital and credit risk are negatively associated change over the period (1998-2003). In addition, Leaven and Levine (2009) analyzed a sample of banks from 48 countries during the period (1996-2001) and they found that capital needs and more stringent restrictions on the bank's activities are associated with a higher risk to banks with shareholders powerful enough.

But the opposite is true in the case of very widespread bank when the domination of shareholders is very high. On the other hand, Partick, Reinhard, Ruxie (2009) studied the effect of regulatory capital on the behavior of risk taking by commercial banks. They observed that different regulations depending on capital market structures of banking sector.

In the level of concentration of market (Note 3), capital regulation is effective in changing the risk taking of the bank because the value of concession ${ }^{4}$ is low and banks have incentives to practice risky strategies to increase their franchise values.

When the value of the concession (Note 4) is strong, the effect of capital regulatory on the bank risk is ambiguous because banks lack these incentives. Indeed, the literature shows that capital adequacy rules have an impact on bank behaviour in two ways. First, the introduction of capital adequacy rules will strengthen the bank's capital and improve the protection of banks to negative shocks. Also, the level of capital adequacy set standards high capital requirement for lending to the private sector for loan for the public sector. Heid (2007) studied the problem of capital, bank loan cycles and their effects on the macro- economy in general. He found that the minimum capital requirements on banks increases the regulation of Basel 2 plays a critical role in reducing the volatility of capital requirements.

In the Tunisian context, Bouri and Ben Hmida (2006) using simultaneous equations, they showed that the relationship between changes in capital and risk is dynamic and multidimensional that reflects a change in bank behaviour studied not only to adapt the regulation but also to better identify risks that threaten bank intermediation.

On the other hand, Terhi and Alistair (2010) studied a sample of US banks between (1986-2008). They examined this relationship between capital and risk adjustments in the bank's portfolios. They found that this relationship is positive.

Whyove et al. (2010) analyzed a sample of 99 banks over the period (2004-2007). They found that a higher capital level is associated with more risk and profitability. Betty and Gron (2001) examined a sample of banks in USA between (1986-1995). They showed that capital regulation has a significant effect to decrease the level of capital in some banks but not in others. Besides, Fatnassi, Hasnaoui, Ftiti (2014) studied 13 banks in the GCC countries over the period (2003-2011). They found that highly capitalized banks are more risky. Looking at the Asian data, Agusman et al. (2008) studied 46 banks and found a negative relationship between (equity / total assets) and the risk but this relationship is not significant.

By examining a large data of 2276 Asian banks in 42 countries, Lee and Hsieh (2013) concluded that there is a positive relationship between capital and risk. Haq and Heaney (2012) studied a panel of 117 banks in 15 European countries over the period (1996-2011). They found a U relationship between capital and banking risk.

They showed that bank risk initially decreases with increasing bank capital, to the level that the capital increase, the bank risk increases. Moreover, Athansoglou (2011) examined the simultaneous relationship between bank capital and risk. He used unbalanced panel of SEE banks from (2001-2009). A key result for the whole sample of bank is the relationship between regulatory capital and risk which is positive. However, a positive two -way relationship between regulatory capital and risk has found only in less than adequately capitalized banks, which also increased substantially their risk in 2009. Employing data on over 100 GCC banks for (1996-2011), Gosh (2014) tested the relationship between risk and capital. The risk is measured by the Zscore, while capital is computed as the ratio of equity to assets, the findings indicate that banks generally increase capital in response to an increase in risk and not vice versa.

Abba et al. (2013) studied a sample of 22 banks in Nigeria from (2007-2011). They found that there is as significant negative relationship between risk and capital adequacy ratio of banks, which means when risk level rises, capital adequacy ratio falls in the Nigerian banking industry.

Ayaydin and Kkarakaya (2014) studied 23 Turkish commercial banks over the period (2003-2011). They find evidence that the effect of increasing bank capital on risk is significantly positive and negative supporting the 
regulatory hypotheses and moral hazard hypotheses respectively.

Gual (2011) reviewed the theoretical and empirical arguments behind the increase in capital requirement proposed by the Basel 3 regulation. It is shown that the new regulation are unlikely diminish risk taking in the banking industry and that the increased capital requirement most likely will lead to increased costs of funding for the industry with adverse consequences for the real economy.

Hishamuddin et al. (2014) studied banks in Malaysia from December 2006 to October 2013. They found that high capital growth and capital buffers provides an extra cushion for Malaysian banks to pursue relatively risky financing activities.

Dao and Ankinbrand (2014) studied the banks in Vietnam. They found that the risk is positively related with capital.

Therefore, there is an increased literature about bank capital and bank risk, but there is no consensus on their relationship.

\section{Empirical Study}

We will use a sample of 18 banks belonging to the professional association of banks in Tunis over the period (2000-2010), the financial data are collected from the professional association of banks in Tunis and the bank's annual reports. Macroeconomic indicators are collected from the national institute of statistics and the central bank of Tunisia.

Table 1. Sample of banks

\begin{tabular}{ll}
\hline Index of bank & Name of bank \\
\hline AB & AMEN BAN \\
ABC & ARAB BANKING CORPORATION \\
ATB & ARAB TUNISIAN BANKING \\
Attijari bank & Atiijari Bank of Tunisia \\
BH & Bank of Housing \\
BT & Bank of Tunisia \\
BTE & Tunisia and Emirate Bank \\
BIAT & Arab International bank of Tunisia \\
BNA & National agriculture bank \\
BTS & Tunisian solidarity bank \\
BTL & Tunisian lybian bank \\
CB & CITI BANK \\
STB & Tunisian banking company \\
SB & STUSID BANK \\
TQB & Tunisian Qatari bank \\
UBCI & Banking Union of trade and industry \\
UIB & International banking Union \\
BTK & Tuniso Kwaiti Bank \\
\hline
\end{tabular}

We will use the static panel because we have individual banks based on the number of years (2000....2010). Also to control the heterogeneity of individuals (Pirott, 2011).

\subsection{Specification of Model}

The model studied is :

$$
\begin{gathered}
\text { Risk }_{i, t}=a 0+b 1 . \text { Size }_{i, t}+b 2 . C A P_{i, t}+b 3 . T L A_{i, t}+b 4 . R^{\prime} O A_{i, t}+b 5 . R O E_{i, t}+b 6 . C E A_{i, t}+b 7 . \text { Tdeposit }_{i, t}+ \\
\text { b8.CPC } C_{i, t}+b 9 \cdot A L A_{i, t}+b 10 . C F C_{i, t}+b 11 . T P I B_{i, t}+b 12 . T I N F_{i, t}+E_{i, t}
\end{gathered}
$$

$\mathrm{i}=$ bank

$\mathrm{t}=$ time;

a0, b1, b2, b3, b4, b5, b6, b7, b8, b9, b10, b11, b12: parameters to be estimated

$$
\operatorname{Risk}=\left(\frac{\sigma(R O A)}{E(R O A)+C A P}\right) 2
$$


Risk = insolvency risk of bank(Teresa \& Dolores, 2008).

$\sigma(\mathrm{ROA})=$ standard deviation of return on assets;

$\mathrm{E}(\mathrm{ROA})=$ expectation of return on assets;

$\mathrm{CAP}=$ equity / total assets;

Size $=$ logarithm of total assets;

The size shows the ability of the bank to win and take risks. The big banks can make diversification of operations which reduces bank risk.

$\mathrm{CAP}=$ equity / total assets;

CAP show the capitalization of bank. Generally more capital can meet the shock and excessive risks.

TLA = total loans / total assets;

TLA shows the percentage of loans in relation to total assets TLA shows the bank's market power in the provision of credit. More TLA increases, the risk increases.

$\mathrm{ROA}=$ net profits / total assets;

The net results shows the profit made by the bank after the market operations, operations with customers also shows bank profitability. More ROA increases, the bank may face the risk of hazard.

$\mathrm{ROE}=$ net income / equity;

ROE shows the profitability of equity. It is important to point of view of shareholders.

$\mathrm{CEA}=$ operating expenses / total assets;

CEA shows the share of operating expenses relative to total assets. More CEA increases, bank risk increases, prompting banks to reduce operating expenses for effective bank management

$\mathrm{T}$ deposit $=$ total deposits $/$ total assets;

$\mathrm{T}$ deposit shows the share of deposits relative to total assets. Usually the deposits are used to finance credit operations.

$\mathrm{CPC}=$ equity / total loans;

CPC shows the share of capital in credits operations. CPC should be low to reduce the credit risk.

$\mathrm{CFC}=$ financial expenses / total loans;

CFC shows the share of financial charges on total credits.

$\mathrm{ALA}=$ liquid assets / total assets;

ALA shows the share of liquid assets to total assets.

TPIB $=$ growth rate of GDP.

TINF $=$ rate of inflation.

\subsection{Econometrics Tests}

\subsubsection{Multi-Colinearity Test}

Mutli-colineartiy appears when 2 or more explanatory variables are correlated and positive similar information. In this situation, the coefficient estimates may change erratically in response to small change in the model or data.

The consequence of high multi-colinearity are (increase of the standard error of $\beta$, reduce reliability), the results are often confusing and misleading. Collinearity detection is done by calculating the correlation between the variables. 
Table 2. Correlation between variables

\begin{tabular}{llllll}
\hline & Risk & Size & CAP & TLA & ROA \\
\hline Risk & 1.000 & & & & \\
Size & 0.1327 & 1.000 & & & \\
CAP & -0.1493 & -0.4423 & 1.000 & & \\
TLA & -0.0569 & 0.2600 & 0.0171 & 1.000 & \\
ROA & 0.0549 & -0.1208 & 0.3815 & -0.1608 & 1.000 \\
ROE & 0.0395 & 0.2760 & -0.1122 & -0.0964 & 0.1532 \\
CEA & 0.3268 & 0.0955 & -0.1581 & -0.1448 & -0.1253 \\
T deposit & 0.3120 & 0.4116 & -0.5023 & -0.2069 & -0.1496 \\
CPC & -0.0879 & -0.5282 & 0.7829 & -0.0771 & 0.5535 \\
ALA & -0.0910 & -0.1167 & 0.0634 & -0.1049 & 0.0213 \\
CFC & 0.1226 & -0.0058 & -0.1023 & -0.1215 & -0.0888 \\
TPIB & 0.0849 & 0.0646 & -0.0656 & 0.0994 & 0.1984 \\
TINF & 0.0778 & 0.1809 & -0.1582 & 0.0518 & -0.0028 \\
\hline
\end{tabular}

Table 3. Suite of correlation between variables

\begin{tabular}{lllllllll}
\hline & ROE & CEA & Tdeposit & CPC & ALA & CFC & TPIB & TINF \\
\hline ROE & 1.000 & & & & & & & \\
CEA & 0.1025 & 1.000 & & & & & & \\
Tdeposit & 0.1550 & 0.5322 & 1.000 & & & & & \\
CPC & -0.1053 & -0.2513 & -0.5516 & 1.000 & & & & \\
ALA & -0.0347 & -0.0853 & -0.1281 & 0.0524 & 1.000 & & & \\
CFC & 0.0435 & 0.4619 & 0.3067 & -0.1314 & -0.0485 & 1.000 & & \\
TPIB & -0.0640 & -0.0019 & 0.0177 & 0.0443 & -0.0850 & 0.0804 & 1.000 & \\
TINF & 0.0470 & -0.1563 & 0.1587 & -0.1294 & -0.1397 & 0.014 & -0.1375 & 1.000 \\
\hline
\end{tabular}

There is a problem in CPC (relation $78 \%$ with CAP). We eliminate CPC.

Table 4. Test of VIF

\begin{tabular}{lll}
\hline Variable & VIF & $\mathbf{1 / V I F}$ \\
\hline CPC & 4.82 & 0.207 \\
Size & 3.01 & 0.332 \\
Tdeposit & 2.95 & 0.338 \\
CAP & 2.85 & 0.350 \\
CEA & 1.87 & 0.534 \\
ROA & 1.85 & 0.541 \\
TLA & 1.38 & 0.724 \\
CFC & 1.33 & 0.751 \\
TINF & 1.27 & 0.786 \\
TPIB & 1.21 & 0.827 \\
ROE & 1.19 & 0.840 \\
ALA & 1.13 & 0.882 \\
\hline
\end{tabular}

Therefore the model will be estimated is:

$$
\begin{gathered}
\text { Risk }_{i, t}=a 0+b 1 . \text { Size }_{i, t}+b 2 . C A P_{i, t}+b 3 . T L A_{i, t}+b 4 . R O A_{i, t}+b 5 . R O E_{i, t}+b 6 . C E A_{i, t}+b 7 . \text { Tdeposit }_{i, t}+ \\
\text { b8.ALA } A_{i, t}+b 9 . C L C_{i, t}+b 10 . T P I B_{i, t}+b 11 . T I N F_{i, t}+E_{i, t}
\end{gathered}
$$$$
\mathrm{i}=\text { bank; }
$$$$
\mathrm{t}=\text { time. }
$$

\subsubsection{Test of Hausman}

It determines if the individual effects are fixed or random. It determines if the beta coefficients of two fixed and 
random or estimates are not statistically different. Under the null hypothesis of independence between the errors and the explanatory variables, both estimators are unbiased, so the estimated coefficients become little different. The fixed effect model assumes that the influence of explanatory variables on the dependent variable is the same for all individuals, regardless of the period.

The random effect model assumes that the relationship between the dependent variable and the explanatory variables no longer fixed but random, individual effect is not a fixed parameter, but a random variable (Bourbonnais, 2009).

\subsubsection{Test of Heteroscedasticity}

There is an heteroscedasticity of residuals if they do not all have the same variance. To detect heteroscedasticity, we apply 2 tests (test Breush Pagan, the wald test), the general idea of these test is to verify whether the residues square can be explained by the explanatory variables of the model.

The Breush Pagan test allows us to detect intraindividual heteroskedasticity which assumes different variance between the errors terms in the same individual.

Pvalue is greater than $1 \%$, there is no problem of heteroskedasticity.

\subsection{Analysis of Descriptive Statistics}

Table 5. Descriptive statistics

\begin{tabular}{llllll}
\hline & Observations & Mean & Standard deviation & Minimum & Maximum \\
\hline Risk & 198 & 0.009173 & 0.0206 & 0 & 0.1659 \\
Size & 198 & 13.67853 & 1.315 & 10.19 & 15.72 \\
CAP & 198 & 0.19866 & 0.200 & 0 & 0.97 \\
TLA & 198 & 0.6711 & 0.196 & 0.071 & 0.957 \\
ROA & 198 & 0.0127 & 0.017 & 0 & 0.1291 \\
ROE & 198 & 0.0769 & 0.088 & 0 & 0.9572 \\
CEA & 198 & 0.027 & 0.010 & 0.0024 & 0.055 \\
T deposit & 198 & 0.648 & 0.278 & 0.0066 & 0.97 \\
ALA & 198 & 0.047 & 0.055 & 0.0045 & 0.44 \\
CFC & 198 & 0.035 & 0.027 & 0.0023 & 0.3179 \\
TPIB & 198 & 0.039 & 0.011 & 0.02 & 0.0611 \\
TINF & 198 & 0.042 & 0.013 & 0.03 & 0.078 \\
\hline
\end{tabular}

-The average of risk is $0.91 \%$. The standard deviation is $2.06 \%$. There is a significant difference between banks at risk of insolvency. The average of size is 13.67 . The standard deviation is 1.31 . There is a significant difference between at level of size.

-The average of CAP is 0.198 . The standard deviation is 0.2005 . It has not significant difference between banks at the level of CAP. The average of TLA is $67 \%$. The credits represent on average $67 \%$ of total assets. As a result, the banks give importance to credits operations. The standard deviation is high. So, there is a significant difference between banks to credit level.

-The average of ROA is $1.27 \%$. Net income is on average $1.27 \%$ of total assets. The standard deviation is low. So, there is not a significant difference between banks in level of return on assets. The average of ROE is $7.69 \%$. The net income is on average $7.69 \%$ of equity. The standard deviation is low. So, there isn't a significant difference between banks in level of return of equity.

-The average of CEA is $2.7 \%$. The operating expenses represent $2.7 \%$ of total assets. The standard deviation is low. There isn't a significant difference between banks in level of CEA.

-The average of Tdeposit is $64.8 \%$. Total deposit represent $64.8 \%$ of total assets. The standard deviation is high. There is a significant difference between banks in level of Tdeposit. The average of ALA is $4.7 \%$. Total liquid assets represent $4.7 \%$ of total assets. The standard deviation is high. There is a significant difference between banks in level of ALA.

-The average of CFC is $3.5 \%$. The financial expenses represent $3.5 \%$ of total credits. The standard deviation is low. There isn't a significant difference between banks in level of CFC.The average of TPIB is $3.9 \%$. The standard deviation is low. There isn't a significant difference in TPIB between (2000-2010) in Tunisia. 
-The average ofTINF is $4.22 \%$. The standard deviation is low. There isn't a significant difference in TINF between (2000-2010) in Tunisia.

\subsection{Estimation and Interpretation of Model}

Table 6. Estimation results

\begin{tabular}{llllll}
\hline Risk & Coefficient & Standard error & $\mathbf{Z}$ & $\mathbf{Z}<\mathbf{P}$ & $\mathbf{9 5 \%}$ Confiance intervalle \\
\hline Size & -0.0010926 & 0.0017 & -0.63 & 0.526 & -0.00440 .00 \\
CAP & -0.012401 & 0.0110 & -1.13 & 0.260 & -0.0330 .009 \\
TLA & 0.0002402 & 0.0078 & 0.03 & 0.976 & -0.01500 .01 \\
ROA & 0.0462319 & 0.104 & 0.44 & 0.658 & -0.1580 .25 \\
ROE & -0.0133178 & 0.016 & -0.83 & 0.409 & -0.0440 .01 \\
CEA & 0.6729943 & 0.175 & 3.83 & 0.000 & 0.321 .01 \\
Tdepsoit & 0.0096315 & 0.008 & 1.19 & 0.233 & -0.00620 .02 \\
ALA & 0.0001482 & 0.025 & 0.01 & 0.995 & -0.0480 .04 \\
CFC & -0.0492457 & 0.054 & -0.90 & 0.367 & -0.15620 .05 \\
TPIB & 0.1199457 & 0.125 & -0.41 & 0.339 & -0.01170 .001 \\
TINF & 0.1685402 & 0.1069 & 0.96 & 0.115 & -0.1250 .3 \\
Constant & -0.013 & 0.026 & -0.59 & 0.555 & -0.0590 .032 \\
\hline
\end{tabular}

Therefore, the model estimated is:

$$
\begin{gathered}
\text { Risk }_{i, t}=-0.013-0.0010926 . \text { Size }_{i, t}-0.012401 . \text { CAP }_{i, t}+0.0002402 . \text { TLA }_{i, t}+0.0462319 . \text { ROA }_{i, t} \\
-0.0133178 . \text { ROE }_{i, t}+0.6729 . \text { CEA }_{i, t}+0.0096 . \text { Tdeposit }_{i, t}+0.0001482 . \text { ALA }_{i, t}-0.049 . \text { CFC }_{i, t} \\
+0.1199 . \text { TPIB }_{i, t}+0.168 . \text { IINF }_{i, t}+E_{i, t}
\end{gathered}
$$

$\mathrm{Z}=\mathrm{t}$ of student.

-There is a negative relationship between risk and size (if the size increases by $1 \%$, the risk decreases by $0.0010926 \%$ ). The increase in size causes diversification operations that reduce the risk of bank. It the same result found by Hakimi et al. (2012), Zribi and Boujelbène (2011), Salked (2011) but contrary to the result found by Teresa and Dolores (2008).

-There is a negative relationship between risk and capital (if capital increases by $1 \%$, the risk decreases by $0.0124 \%$ ). The increase in equity has a negative effect on bank risk. The equity augmentation improves the bank ability to cope with financial shocks. (Berger, 1995). But this relationship is not statistically significant. It is the same result by Zribi and Boujelbène (2011) Salked (2011) but this is contrary to result found by Hakimi et al. (2012).

-There is a positive relationship between risk and TLA (TLA increases by $1 \%$, The risk increases by $0.00024 \%$ ). Increases in total loans has a positive effect on bank risk. The credit growth can increase the number of borrowers default which increasing bank risk.

This is the same result found by Salked (2011).

-There is a positive relationship between risk and ROA (if ROA increase by $1 \%$, the risk increases by $0.046 \%$ ). Increase in return of assets ha a positive effect on bank risk. The increase in net income can encourage banks to make risky operations diversification or growth which increases the bank risk.

-There is a negative relationship between risk and ROE (if ROE increases by $1 \%$, the risk decreases by $0.0133 \%$ ). The increase of return on equity has a negative effect on bank risk. This is contrary to result found by Teresa and Dolores (2008).

-There is a positive relationship between risk and $\mathrm{T}$ deposit (if Tdeposit increase by $1 \%$, Risk increase by $0.0096 \%$ ). The increase of $\mathrm{T}$ deposit has a positive effect on bank risk. This is similar a result found by Salked. M (2011).

There is a positive relationship between risk and ALA (if ALA increase by 1\%, Risk increases by $0.0001482 \%$ ). The increase of liquid assets has a positive effect on bank risk. The increase in liquid assets reduces profitable investment opportunities by banks which increases their risk.

There is a negative relationship between risk and CFC (if CFC increase by $1 \%$, risk decreases by $0.049 \%$ ). The 
increase of financial expenses has a negative effect on bank risk.

-There is a positive relationship between risk and TPIB (if TPIB increase by $1 \%$, risk increase by $0.11 \%$ ). The increase of growth of PIB has a positive effect on bank risk. This is contrary to result found by Salked. M (2011). There is a positive relationship between risk and TINF (if TINF increase by $1 \%$, risque increase by $0.168 \%$ ). The increase of inflation has a positive effect on bank risk.

The increase in inflation can lead to higher costs for banks which reduces the risk of bank insolvency. This is consistent with result found by Hakim et al. (2012), Salked (2011).

\section{Conclusion}

The capital and risk are two important variables in the banking literature. As a result, their relationship is interesting fro managers, shareholders, researchers. In the context of this article, we used a sample of 18 banks over the period (2000-2010), we found a negative relationship between capital and bank risk, when the capital increases, the bank risk decreases. This is similar to several studies, showing risk aversion for banks in Tunisia and incentives to increase their capital.

\section{References}

Abba, G. O., Zadrariah, P., \& Ingang, E. E. (2013). Capital adequacy ratio and banking risk in the Nigerian money deposit banks. Research Journal of Finance and Accounting, 4(17), 17-25.

Aggrawal, R., \& Jacques, K. (2001). The impact of FDICIA and prompt corrective action on bank capital and risk: Estimates using a simultaneous equations model. Journal of Banking and Finance, 25, 1139-1160. http://dx.doi.org/10.1016/S0378-4266(00)00125-4

Agusman, A., Monroe, G. S., Gasbarro, D., \& Zumwalt, J. K. (2008). Accounting and capital market measures of risk: Evidence from Asian banks during (1998-2003). Journal of Banking and Finance, 480-488. http://dx.doi.org/10.1016/j.jbankfin.2006.06.018

Athansoglou, P. P. (2011). Bank capital and risk in the South Eastern European region (pp. 5-38). Retrieved from http://www.bankofgreece.gr

Ayadin, N., \& Karakaya, A. (2014). The effect of bank capital on profitability and risk in Turkish banks. International Journal of Business and Social Sciences, 5(1), 252-271.

Baltagi, H. B., Fingleton, B., \& Pirott, A. (2014). Estimating and forecasting with a dynamic spatial: Panel data model. Oxford Bulletin of Economics and Statistics, 76(1), 112-124. http://dx.doi.org/10.1111/obes.12011

Beatty, A., \& Gron, A. (2011). Capital, portfolio and growth: Bank behavior under risk based capital guidelines. Journal of Financial Services Research, 20(1), 5-31. http://dx.doi.org/10.1023/A:1011146725028

Bourbonnais, R. (2009). Econométrie. Retrieved from http://www.numilog.com

Bouri, A., \& Ben Hmida, A. (2006). Capital and risk taking of banks under regulation: A simultaneous equation approach in the Tunisian context. Sixième congrés international de l'AFFI, Finance d'entreprise et finance de marché, quelles complémentarités? Tunisia 2006.

Calem, P., \& Rob, R. (1999). The impact of capital based regulation on bank risk taking. Journal of Financial Intermediation, 8, 317-352. http://dx.doi.org/10.1006/jfin.1999.0276

Dao, B. H., \& Ankenbrand, T. (2014). Capital adequacy and banking risk: An empirical study of Vietnamese banks. Retrieved from http://papers.ssrn.com

Editz, T., Michael, I., \& Perrandin, W. (1998). The impact of capital requirement on UK bank behavior. Reserve Bank of New York Policy Review, 4(3), 15-22.

Fatnassi, I., Hasnaoui, H., \& Ftiti, Z. (2014). The impact of bank capital on profitability and risk in GCC countries: Islamic vs conventional.

Ghosh, S. (2014). Risk, capital and financial crises: Evidence from GCC banks. Borsa Istanbul Review, 14(3), 145-157. http://dx.doi.org/10.1016/j.bir.2014.06.003

Godlewski, C. J. (2004). Capital regulation and credit risk taking: Empirical evidence from banks in emerging market economies.

Gual, J. (2011). Capital requirements under Basel II and their impact on the banking industry (pp. 5-17). Retrieved from http://www.laicaixaresearch.com

Hakimi, A., Dkhili, H., \& Khlaifia, W. (2012). Universal banking and credit risk: Evidence from Tunisia 
International Journal of Economics and Financial Issues, 2(4), 496-504.

Haq, M., \& Heaney, R. (2012). Factors determining European bank risk. Journal of International Financial Market Institutions, and Money, 22, 696-718. http://dx.doi.org/10.1016/j.intfin.2012.04.003

Heid, F. (2007). Cyclical implication of minimum capital requirements. Journal of Banking and Finance, 31, 3885-3900. http://dx.doi.org/10.1016/j.jbankfin.2007.03.004

Jacques, K., \& Nigro, P. (1997). Risk based capital, portfolio risk, and bank capital: A simultaneous equations approach. Journal of Economics and Business, 49(6), 533-547. http://dx.doi.org/10.1016/S0148-6195(97)00038-6

Jokibi, T., \& Milne, A. (2011). Bank capital buffer and risk adjustments decisions. Journal of Financial Stability, 7(3), 165-178. http://dx.doi.org/10.1016/j.jfs.2010.02.002

Kahane, Y. (1977). Capital adequacy and the regulation of financial intermediaries. Journal of Banking and Finance, 1, 207-218. http://dx.doi.org/10.1016/0378-4266(77)90007-3

Kareken, J. H., \& Wallace, N. (1978). Deposit insurance and bank regulation: A partial-equilibrium exposition. Journal of Business, 51, 413-438. http://dx.doi.org/10.1086/296006

Kim, D., \& Santomero, A. M. (1988). Risk in banking and capital regulation. Journal of Finance, 43, 1219-1233. http://dx.doi.org/10.1111/j.1540-6261.1988.tb03966.x

Laeven, L., \& Levine, R. (2009). Bank governance, regulation and risk taking. Journal of Financial Economics, 4. http://dx.doi.org/10.1016/j.jfineco.2008.09.003

Lee, C. C., \& Hsieh, M. F. (2013). The impact of bank capital on profitability and risk in Asian banking. Journal of International Money and Finance, 32, 251-284. http://dx.doi.org/10.1016/j.jimonfin.2012.04.013

Lin, S. L., Hwang, D. Y., Wang, K. L., \& Xie, Z. W. (2013). Banking capital and risk taking adjustment under capital regulation: The role of financial freedom, concentration and governance control. International Journal of Management, Economics and Social Sciences, 2(2), 99-128.

Marshall, D. A., \& Prescott, E. S. (2000). Bank capital requirement with and without state contingent penalties. Working paper series.

Porter, R. L. (2009). The impact of bank capital requirement on bank risk: An econometric puzzle and a proposed solution. Banks and Banks systems, 4(1), 55-61.

Salked, M. (2011). Determinants of bank's total risk: Accounting ratios and macroeconomic indicators.

Santos, J. A. (1999). Bank capital and equity investment regulation. Journal of Banking and Finance, 23, 1095-1120. http://dx.doi.org/10.1016/S0378-4266(98)00132-0

Sharp, W. F. (1977). Bank capital adequacy, deposit insurance and security values. NBER working paper, 209.

Shrieves, R. E., \& Dahl, D. (1992). The relationship between risk and capital in commercial banks. Journal of Banking and Finance, 16(2), 439-457. http://dx.doi.org/10.1016/0378-4266(92)90024-T

Teresa, G., \& Dolores, R. M. (2008). Risk taking behavior and ownership in the banking industry: The Spanish evidence. Journal of Economics and Business, 60(4), 125-148.

Zribi, N., \& Boujelbène, Y. (2011). The factors influencing bank credit risk: The case of Tunisia. Journal of Accounting and Taxation, 3(4), 70-78.

\section{Notes}

Note 1. The results of the works of Shrieves et Dahl (1992), Jacques and Nigro (1997), Aggrawal and Jacques (1997), Editz et al (1998) which are based on simultaneous equation models showed that regulatory capital constraints exert significant influence over the financial decisions of banks and confirmed the effectiveness of capital regulation in the sense that it has led to higher capital ratio.

Note 2. Jacques and Nigro (1997) showed that the introduction of capital standards based in risk lead to a significant increase in capital ratios and reduction of bank portfolio risk which already meet regulatory requirements.

Note 3. The market with many banks.

Note 4 . The value of future cash-flows discounted at the bank. 


\section{Copyrights}

Copyright for this article is retained by the author(s), with first publication rights granted to the journal.

This is an open-access article distributed under the terms and conditions of the Creative Commons Attribution license (http://creativecommons.org/licenses/by/3.0/). 